\title{
IMPLEMENTATION OF COOPERATIVE LEARNING MODEL NHT TO TRAIN STUDENTS COMMUNICATION SKILL IN ACID BASE MATTER
}

\author{
Lelly Puspitasari ${ }^{1}$, Muchlis ${ }^{2 *}$ \\ Jurusan Kimia, FMIPA, Universitas Negeri Surabaya \\ *Corresponding author: muchlis@unesa.ac.id
}

\begin{abstract}
The aim of this research is to description the implementation of cooperative learning model NHT, students activity and practice communication skills through material of acid base. The research design used is "One Shoot Case Study". Research data obtained include (1) Implementation of cooperative learning model NHT to get a score at meetings 1, 2, and 3 of 3,86, 3,90, and 3,95 with very good category. (2) Students use their time to practice communication skills asking for 3 meetings of 14,07\%, whereas to practice the opinion skills of 66,29\%. (3) Communication skills of students who are trained obtain sufficient criteria on the quantity of questions with a percentage for three consecutive meetings of $25 \% ; 44,44 \%$; and 55,56\% and the quantity of opinion students get a good assessment criteria of 41,67\%; $61,11 \%$; and $75 \%$. On the quality of asking students get an excellent title for three consecutive meetings $8,33 \% ; 11,11 \%$; and $25 \%$ and the quality of opinion students of 5,56\%; 25\%; and $27,78 \%$.
\end{abstract}

Keyword: cooperative learning model NHT, communication skill, acid base.

\section{PENDAHULUAN}

Pendidikan menjadi hal yang sangat penting untuk melahirkan generasi penerus bangsa. Pada abab 21 ini semakin banyak tantangan yang dihadapi sesuai dengan tuntutan seiring perkembangan pendidikan pada masa sekarang. Tuntutan tersebut dapat dilihat dari kompetensi atau skill yang bukan hanya untuk merubah ranah pengetahuan, namun juga membentuk karakter dan sikap mental bagi peserta didik. Sehingga usaha dalam menghadapi tantangan tersebut yaitu dengan meningkatkan mutu pendidikan agar tujuan dalam pendidikan nasional dapat tercapai. Pencapaian tersebut dapat dilakukan dengan pengembangan kurikulum 2013. Perancangan kurikulum 2013 dimaksudkan mewujudkan tujuan pendidikan yang memiliki karakteristik yakni pengembangan keterampilan sosial, akademik, dan vokasional (Depdiknas, 2013). Salah satu ilmu diamanatkan dalam kurikulum adalah ilmu kimia.

Kimia merupakan mata pelajaran yang kompleks, tidak hanya mencakup konsep perhitungan, tetapi juga melaksanakan praktikum dalam penerapan ilmu kimia di kehidupan sehari-hari. Salah satu materi dalam pembelajaran kimia yaitu asam basa. Karakteristik dalam materi asam basa adalah peserta didik dapat melakukan analisis sifat larutan yang berdasar pada konsep asam basa dan juga $\mathrm{pH}$ larutan, serta dapat mengemukakan ide terhadap pengunaan indikator yang paling tepat dalam penentuan sifat asam basa.

Berdasarkan hasil pra-penelitian pada kelas XII IPA 1 sebanyak $45,71 \%$ peserta didik menyatakan bahwa materi yang sulit dipahami dalam pembelajaran kimia adalah materi asam basa. Pada hasil angket $37,14 \%$ materi tersebut dianggap sulit karena banyak perhitungan dan $42,86 \%$ materi tersebut dianggap sulit karena banyak hafalan. Selain itu didukung hasil angket dari peserta didik kelas XI IPA 7 yang menyatakan bahwa $84,85 \%$ peserta didik yang pasif seperti tidak aktif bertanya maupun berpendapat ketika belajar secara berkelompok di kelas. Hasil yang diperoleh menunjukkan jika keaktifan peserta didik pada proses pembelajaran masih rendah dan guru lebih mendominasi saat proses pembelajaran berlangsung. 
Berdasarkan fakta tersebut materi asam basa membutuhkan beberapa keterampilan, salah satu keterampilannya yaitu komunikasi. Keterampilan komunikasi yang dimiliki peserta didik menjadi komponen yang sangat penting yang harus diperhatikan. Komunikasi adalah proses yang dikehendaki setiap orang dalam menata lingkungan sekitarnya dengan cara membangun suatu hubungan antar manusia, melalui pertukaran informasi (Cangara, 2016) Salah satu unsur terpenting dalam keterampilan komunikasi adalah sebagai penentu keberhasilan proses pembelajaran, dimana terjadi pemindahan ilmu dari yang memberi pesan (komunikator) yaitu guru ke peserta didik sebagai yang menerima pesan (komunikan) (Rosyada, 2004). Keterampilan komunikasi meliputi keterampilan berpendapat dan bertanya.

Membudayakan keterampilan komunikasi peserta didik satu diantaranya dapat dilakukan melalui suatu pembelajaran yang aktif yang sesuai untuk melatihkan keterampilan komunikasi salah satunya yaitu model pembelajaran kooperatif. Pembelajaran dengan menggunakan model kooperatif merupakan pembelajaran dimana peserta didik bekerja dan belajar dalam gabungan kelompok kecil secara berkolaborasi dengan setiap kelompok memiliki anggota 4-6 orang dengan struktur kelompok yang heterogen. Prinsip yang sesuai dengan pembelajaran model kooperatif yaitu dibentuk kelompok dari peserta didik yang mempunyai pengetahuan tinggi, pengetahuan sedang, maupun pengetahuan rendah (Slavin, 2016).

Tipe pembelajaran pada model kooperatif satu diantaranya yakni tipe Numbered Heads Together (NHT). Adapun pada tipe pembelajaran NHT terdapat empat hal pokok yakni 1) Pemberian nomor (Numbering), 2) Pengajuan pertanyan (Questioning), 3) Berpikir bersama-sama (Heads Together), dan 4) Memberi Jawaban (Answering). Pada pembelajaran model kooperatif tipe ini digunakan sebagai sarana agar dapat melihat keterampilan sosial peserta didik selama proses pembelajaran yang berlangsung di kelas. Keterampilan yang perlu dikembangkan salah satunya adalah keterampilan berkomunikasi (Arends, 2013).

\section{METODE}

Jenis pada penelitian ini yaitu deskripsi kuantitatif dengan desain penelitiannya yaitu "One Shoot Case Study", yaitu penelitian ini dilaksanakan hanya pada satu kelas saja dan tidak ada kelas pembanding yang akan diberikan penerapan untuk pembelajaran pada model kooperatif tipe NHT serta tanpa Pretest (Sugiyono, 2016).

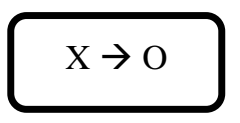

Keterangan :

X :Penerapan pembelajaran model kooperatif tipe NHT pada materi Asam Basa.

$\mathrm{O} \quad$ :Keterampilan komunikasi yaitu keterampilan berpendapat dan bertanya serta hasil belajar peserta didik sebagai data pendukung.

Subjek dalam penelitian ini adalah peserta didik di SMAN 1 Waru Sidoarjo dengan satu kelas sampel yaitu pada kelas XI IPA 7 sebanyak 36 peserta didik. Penelitian yang dilaksanakan semester genap pada tahun ajaran 2019/2020 ini menjadikan peneliti sebagai seorang pengajar yang menggunakan penerapan pada pembelajaran model kooperatif tipe NHT.

Perangkat pembelajaran dalam penelitian ini yang dibuat yakni silabus, RPP, dan LKPD. Sedangkan instrument yang dibuat yaitu lembar pengamatan untuk keterlaksanaan model pembelajaran, lembar pengamatan untuk aktivitas peserta didik, lembar untuk menilai keterampilan komunikasi yang meliputi bertanya dan berpendapat, serta lembar penilaian posttest.

Prosedur penelitian yang digunakan dalam pembelajaran model kooperatif tipe NHT memiliki 3 tahap, yang pertama yaitu persiapan, kedua yakni tahap pelaksanaan, dan ketiga adalah tahap akhir. Metode pengumpulan data digunakan agar penelitian berjalan dengan lancar. Adapun metodenya adalah metode pengamatan yaitu mengamati keterlaksanaan, mengamati aktivitas peserta didik dan mengamati keterampilan komunikasi. Pengamat berjumlah 8 orang dengan 2 orang mengamati keterlaksanaan dan 6 orang mengamati aktivitas serta keterampilan komunikasi peserta didik. Pengamatan keterampilan komunikasi dibantu menggunakan audio visual recorder. Metode 
yang terakhir adalah metode tes yang mana untuk mengukur kemampuan kognitif peserta didik sebagai data pendukung.

Analisis data keterlaksanaan model pembelajaran dilakukan dengan kriteria skor 04. Data hasil pengamatan yang dilakukan oleh para pengamat terhadap keterlaksanaan pembelajaran menggunakan kriteria seperti pada Tabel 1.

Tabel 1 Kriteria untuk Penilaian Keterlaksanaan Model Pembelajaran

\begin{tabular}{cc}
\hline Skor & Kriteria \\
\hline 0 & Tidak terlaksana \\
1 & Buruk \\
2 & Cukup \\
3 & Baik \\
4 & Sangat baik \\
\hline
\end{tabular}

Analisis data keterlaksanaan dari hasil pengamatan yang digunakan dapat dihitung dengan rumus sebagai berikut:

$$
\text { keterlaksanaan }=\frac{\text { jumlah skor yang diperoleh }}{\text { jumlah skor maksimal }} \times 4
$$

Nilai yang diperoleh kemudian dikonversi menggunakan kriteria skor sebagai berikut :

Skor 3,1 - 4 : Sangat baik

Skor 2,1-3 : Baik

Skor $1,1-2$ : Cukup

Skor $0,5-1$ : Buruk

(Riduwan, 2015)

Keterlaksanaan fase pembelajaran dianggap baik jika pada semua fase dalam pembelajaran model kooperatif tipe NHT telah terlaksana dengan skor keterlaksanaan pembelajaran yang diperoleh yaitu $\geq 2,1$ atau berada pada kriteria baik ataupun sangat baik.

Aktivitas peserta didik diamati setiap 3 menit sekali dengan menggunakan rumus:

$\%$ Aktivitas $=\frac{\sum \text { waktu aktivitas yang muncul }}{\sum \text { aktivitas keseluruhan }} \times 100 \%$

Berdasarkan hasil perhitungan tersebut aktivitas peserta didik dikatakn dapat terlaksana dengan baik jika persentase pada aktivitas yang relevan lebih besar dibandingkan dengan aktivitas yang tidak relevan.

Analisis data keterampilan komunikasi yang diperoleh dari hasil pengamatan adalah data kuantitas dan kualitas komunikasi peserta didik yang mencakup bertanya serta berpendapat. Kuantitas komunikasi untuk peserta didik dihitung dari banyaknya peserta didik yang bertanya dan berpendapat selama pembelajaran berlangsung, namun bukan dari banyaknya pertanyaan dan pendapat yang disampaikan oleh peserta didik. Kuantitas komunikasi dihitung menggunakan rumus:

$\%$ Kuantitas Komunikasi $=\frac{\sum \text { siswa berkomunikasi }}{\sum \text { seluruh siswa }} \times 100 \%$

Kualitas bertanya peserta didik akan dianalisis dengan tingkat bertanya Taksonomi Bloom (C1-C4). Sedangkan untuk kualitas berpendapat akan dianalisis dengan menggunakan rumus sebagai indikator berpendapat analitis dan logis. Adapun kualitas komunikasi dikonversi ke dalam bentuk nilai sebagai berikut:

$\%$ Kualitas Komunikasi $=\frac{\sum \text { skor yang diperoleh }}{\sum \text { skor keseluruhan }} \times 100 \%$

Data hasil pengamatan yang diperoleh dianalisis sesuai kriteria yang dapat dilihat pada Tabel 2.

Tabel 2 Kriteria Penilaian Keterampilan Komunikasi

\begin{tabular}{cc}
\hline Persentase & Kategori \\
\hline $0 \%-20 \%$ & Sangat buruk \\
$21 \%-40 \%$ & Buruk \\
$41 \%-60 \%$ & Cukup \\
$61 \%-80 \%$ & Baik \\
$81 \%-100 \%$ & Baik sekali \\
\hline
\end{tabular}

(Riduwan, 2015)

Berdasarkan tabel tersebut keterampilan komunikasi peserta didik dikatakan baik jika mencapai predikat baik dengan persentase $\geq 61 \%$.

Analisis data untuk hasil belajar digunakan sebagai data pendukung yang bertujuan mengetahui hasil ketuntasan belajar peserta didik. Hasil belajar dikatakan tuntas apabila nilai posttest yang didapatkan memenuhi skor ketuntasan individu yang telah ditetapkan oleh SMAN 1 Waru Sidoarjo pada materi asam basa yaitu sebesar $\geq 75$ dan peserta didik dianggap telah tuntas secara klasikal apabila $75 \%$ peserta didik mendapatkan nilai $\geq$ 75. Ketuntasan hasil belajar dihitung berdasarkan rumus sebagai berikut:

$$
\text { Nilai siswa }=\frac{\sum \text { skor yang diperoleh }}{\text { skor maksimal }} \times 100
$$


Persentase ketuntasan klasikal dihitung menggunakan rumus sebagai berikut:

$$
\text { \% Ketuntasan Klasikal }=\frac{\sum \text { siswa yang tuntas }}{\sum \text { seluruh siswa }} \times 100 \%
$$

\section{HASIL DAN PEMBAHASAN}

\section{Keterlaksanaan Model Pembelajaran}

Keterlaksanaan pada pembelajaran model kooperatif pada tipe NHT yang diamati dua orang pengamat menggunakan instrumen lembar pengamatan keterlaksanaan model pembelajaran. Lembar pengamatan keterlaksanaan pembelajaran memiliki tujuan untuk memberikan nilai pada kemampuan guru dalam pengelolaan pembelajaran di kelas serta keterlaksanaan kegiatan pembelajaran sesuai dengan sintaks-sintaks yang terdapat di Rencana Pelaksanan Pembelajaran atau RPP menggunakan pembelajaran model kooperatif tipe NHT selama pembelajaran berlangsung.

Pengamatan pada keterlaksanaan model pembelajaran dilakukan sebanyak 3 kali pertemuan selama $2 \times 45$ menit setiap pertemuannya. Adapun hasil keterlaksanaan pembelajaran dengan model kooperatif dapat dilihat pada Gambar 1.

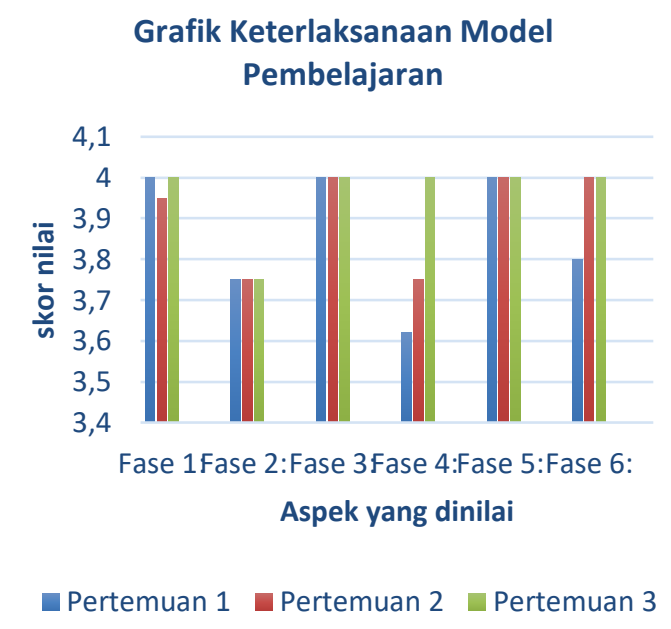

\section{Gambar 1 Persentase Keterlaksanaan Model Pembelajaran pada Tiap Fase}

Keterangan:

Fase ke-1= Menyampaikan tujuan serta memberi motivasi kepada peserta didik

Fase ke-2 $=$ Menyajikan sebuah informasi

Fase ke-3 = Mengorganisasikan peserta didik kedalam kelompok belajar

Fase ke-4 = Membimbing kelompok untuk bekerja dan belajar

Fase ke- $5=$ Evaluasi

Fase ke-6 = Memberikan sebuah penghargaan
Berdasarkan hasil Gambar 1 tersebut memperlihatkan bahwa keterlaksanaan pembelajaran pada model kooperatif tipe NHT telah terlaksana dengan baik disetiap pertemuannya dibuktikan hasil rata-rata keterlaksanaan untuk pertemuan 1,2 , dan 3 secara berurutan adalah 3,$86 ; 3,90$; dan 3,95 sehingga memiliki kategori sangat baik, sehingga guru sudah melaksanakan pembelajaran yang sesuai dengan sintakssintaks model pembelajaran koperatif tipe NHT.

Pembelajaran pada model kooperatif tipe NHT membuat peserta didik dapat lebih aktif dalam proses pembelajaran sehingga sangat cocok untuk melatihkan suatu keterampilan yaitu komunikasi peserta didik yang meliputi keterampilan berpendapat dan bertanya. Hal ini didukung dengan teori belajar konstruktivis yang mengemukakan bahwa guru bukan hanya dapat sekedar membagikan pengetahuan kepada peserta didik. Namun juga harus membangun secara mandiri pengetahuan yang ada dibenak peserta didik (Slavin, 2016). Peserta didik diberikan kesempatan oleh guru dalam penerapan dan penemuan ide-ide mereka sendiri dan guru disini bertindak sebagai fasilitator sehingga pembelajaran akan berpusat pada peserta didik di dalam kelas.

\section{Aktivitas Peserta Didik}

Aktivitas peserta didik diamati guna merekam seluruh aktivitas yang dilakukan peserta didik selama dalam proses pembelajaran dengan menggunakan pembelajaran pada model kooperatif tipe NHT. Pada aktivitas ini akan berdampak terhadap keterlaksanaan pembelajaran dan juga keterampilan komunikasi karena pada kegiatan belajar mengajar akan selalu berkaitan dengan guru serta peserta didik. Tujuan aktivitas peserta didik adalah untuk meyakinkan bahwa keterampilan komunikasi adalah hasil yang didapat setelah menerapkan pembelajaran tipe NHT.

Aktivitas peserta didik yang diamati mencakup 1) mendengarkan serta memperhatikan penjelasan dari guru, 2) mendiskusikan jawaban soal yang terdapat pada LKPD secara berkelompok, 3) mempresentasikan hasil belajar kelompoknya, 4) mengajukan pertanyaan kepada guru maupun kepada kelompok yang sedang melakukan presentasi, 5) menyanggah atau 
memberikan pendapat kepada kelompok yang sedang presentasi, dan 6) menyimpulkan materi pembelajaran. Pengamatan juga dilakukan untuk aktivitas yang tidak relevan seperti bermain handphone, bergurau, mengantuk, berjalan-jalan untuk mengganggu temannya, atau berbicara hal diluar materi pelajaran.

Pada pengamatan aktivitas peserta didik dilakukan 6 orang pengamat, dimana untuk masing-masing pengamat harus mengamati serta menilai aktivitas peserta didik dari satu kelompok yang beranggotakan 6 orang peserta didik heterogen. Pengamat tidak hanya mengamati dan menilai aktivitas peserta didik namun juga mencatat setiap pertanyaan dan pendapat yang disampaikan oleh anggota kelompok, selain itu juga dibantu dengan audio recorder untuk memudahkan merekam keterampilan komunikasi kelompok tersebut. Pengamatan dilakukan dalam rentang waktu 3 menit sekali.

Melalui penerapan pembelajaran model kooperatif tipe NHT ini dapat menjadikan peserta didik belajar bekerja sama dengan anggota kelompoknya dengan baik serta dilatihkannya keterampilan komunikasi, sehingga diharapkan peserta didik lebih belajar menghargai dan menghormati pendapat yang disampaikan oleh temannya. Hubungan aktivitas peserta didik dengan keterampilan komunikasi yaitu persentase aktivitas peserta didik yang relevan dengan keterampilan komunikasi lebih besar daripada persentase aktivitas tidak relevan. Hal ini dibuktikan dengan telah terlatihnya keterampilan komunikasi melalui pembelajaran model kooperatif tipe NHT. Keterkaitan aktivitas peserta didik dengan keterampilan komunikasi disajikan pada Gambar 2.

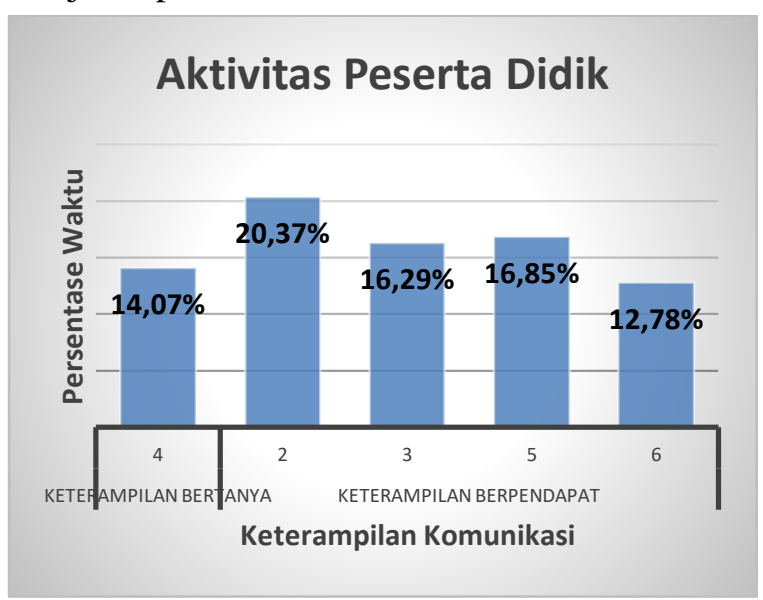

Gambar 2 Jumlah Rata-Rata Persentase Aktivitas Peserta Didik pada Keterampilan Komunikasi

Berdasarkan data pada Gambar 2 memperlihatkan bahwa peserta didik menggunakan waktunya untuk berlatih keterampilan komunikasi bertanya selama 3 pertemuan sebesar $14,07 \%$ pada kode 4 yaitu mengajukan pertanyaan pada guru maupun pada kelompok yang sedang presentasi. Sedangkan untuk keterampilan komunikasi berpendapat peserta didik menggunakan waktunya selama 3 pertemuan sebesar 20,37\% pada kode 2 yaitu mendiskusikan jawaban soal yang terdapat pada LKPD secara berkelompok, pada kode 3 sebesar 16,29\% yaitu mempresentasikan hasil belajar kelompoknya, pada kode 5 sebesar $16,85 \%$ yaitu menyanggah atau memberikan pendapat kepada kelompok yang sedang presentasi, serta pada kode 6 sebesar $12,78 \%$ yaitu menyimpulkan materi pembelajaran. Sehingga peserta didik menggunakan waktunya untuk berlatih keterampilan berpendapat sebesar 66,29\%.

Adapun aktivitas peserta didik pada kode 1 yaitu peserta didik mendengarkan serta memperhatikan penjelasan dari guru tidak termasuk kedalam aktivitas relevan yang berkaitan dengan keterampilan komunikasi, namun aktivitas tersebut termasuk dalam aktivitas yang relevan yang berkaitan dengan model pembelajaraan kooperatif. Berdasarkan uraian tersebut aktivitas peserta didik memiliki peranan penting dalam mendukung keefektifan dan terlaksananya sintaks pembelajaran pada model kooperatif tipe NHT yang dilaksanakan oleh guru. Sehingga hasil persentase aktivitas peserta didik yang relevan dengan keterampilan komunikasi lebih besar daripada aktivitas peserta didik yang tidak relevan.

\section{Keterampilan Komunikasi}

Komunikasi merupakan suatu proses yang dikehendaki setiap orang untuk menata lingkungan sekitarnya dengan cara membangun hubungan antar manusia, lewat pertukaran informasi (Cangara, 2016). Keterampilan komunikasi yang diamati pada penelitian ini mencakup keterampilan bertanya serta berpendapat. Keterampilan berkomunikasi pada peserta didik dianalisis berdasarkan kuantitas serta kualitas keterampilan bertanya dan berpendapat. Kuantitas bertanya diamati dari banyaknya 
peserta didik yang bertanya, bukan dari banyaknya suatu pertanyaan yang disampaikan oleh peserta didik. Data kuantitas bertanya peserta didik dalam tiga pertemuan ditunjukkan pada Tabel 3.

Tabel 3 Persentase Kuantitas Bertanya Peserta Didik

\begin{tabular}{cc}
\hline Pertemuan & $\begin{array}{c}\text { Persentase Kuantitas } \\
\text { Bertanya Peserta Didik }\end{array}$ \\
\hline 1 & $25 \%$ \\
2 & $44,44 \%$ \\
3 & $55,56 \%$ \\
\hline
\end{tabular}

Berdasarkan dari data Tabel 3 menunjukkan bahwa kuantitas keterampilan komunikasi bertanya peserta didik mendapatkan kriteria penilaian cukup karena pada pertemuan pertama persentase yang diperoleh sebesar $25 \%$, pertemuan kedua sebesar 44,44\%, pertemuan ketiga sebesar $55,56 \%$. Kuantitas keterampilan komunikasi bertanya setiap pertemuannya mengalami peningkatan. Persentase ini memperlihatkan peserta didik telah berlatih komunikasi yaitu bertanya dan berpartisipasi aktif selama kegiatan pembelajaran.

Adapun selama tiga pertemuan terdapat peserta didik yang tidak pernah mengajukan pertanyaan yaitu peserta didik dari kelompok 2 yang beinisial IFW, GCJS dari kelompok 3, HSP dari kelompok 4 dan MMA dari kelompok 6. Peserta didik enggan berkomunikasi dalam pembelajaran dikarenakan peserta didik tersebut tidak memperhatikan serta mendengarkan penjelasan dari guru maupun temannya yang lain selama proses pelajaran. Selain itu karena peserta didik tersebut sering berbicara dengan temannya yang lain, sehingga peserta didik tersebut menjadi tidak fokus dalam pembelajaran dan kesempatan untuk berkomunikasi hilang dan sudah diambil oleh temannya yang lain (Maryanti, dkk., 2012).

Peserta didik lebih sulit bertanya daripada sekedar mengemukakan pendapat karena kemampuan menanya merupakan wujud sikap kritis peserta didik terhadapp materi dan pembelajaran yang dilakoninya (Kosasih, 2014). Oleh karena itu, bertanya dapat digunakan untuk mengecek suatu pemahaman materi peserta didik yang dipelajari dalam proses pembelajaran. Namun tidak semua peserta didik memiliki sikap kritis dan juga sikap berani dalam mengajukan pertanyaan sehingga pada keterampilan komunikasi bertanya mendapatkan kriteria penilaian cukup.

Pada kuantitas berpendapat peserta didik juga diamati dari banyaknya peserta didik yang berpendapat, bukan dari banyaknya pendapat yang disampaikan peserta didik. Data kuantitas berpendapat dalam tiga pertemuan ditunjukkan Tabel 4.

Tabel 4 Persentase Kuantitas Berpendapat Peserta Didik

\begin{tabular}{cc}
\hline Pertemuan & $\begin{array}{c}\text { Persentase Kuantitas } \\
\text { Berpendapat Peserta Didik }\end{array}$ \\
\hline 1 & $41,67 \%$ \\
2 & $61,11 \%$ \\
3 & $75 \%$ \\
\hline
\end{tabular}

Berdasarkan data dari Tabel 4 menunjukkan bahwa kuantitas berpendapat peserta didik pada kelas XI IPA 7 termasuk dalam kriteria penilaian baik, dengan diperoleh persentase setiap pertemuannya berturut-turut sebesar $41,67 \%$ pada pertemuan yang pertama, $61,11 \%$ pada pertemuan yang kedua, dan $75 \%$ pada pertemuan akhir. Persentase kuantitas komunikasi berpendapat meningkat seiring dengan aktivitas relevan yang juga meningkat dengan menggunakan pembelajaran model kooperatif tipe NHT ini.

Selama tiga pertemuan terdapat peserta didik yang tidak pernah mengemukakan pendapatnya yaitu peserta didik yang berinisial MBRA dari kelompok 1, MH dari kelompok 5, dan MMA dari kelompok 6. Peserta didik enggan berkomunikasi dalam pembelajaran dikarenakan peserta didik tersebut tidak memperhatikan serta mendengarkan penjelasan dari guru maupun temannya yang lain selama proses pembelajaran. Selain itu karena peserta didik tersebut sering berbicara dengan teman yang lain, sehingga peserta didik tersebut menjadi tidak fokus dalam pembelajaran dan kesempatan untuk berkomunikasi hilang dan sudah diambil oleh temannya yang lain (Maryanti, dkk., 2012).

Meskipun terdapat peserta didik yang tidak pernah mengemukakan pendapatnya, namun banyak juga peserta didik yang selalu 
mengemukakan pendapatnya selama 3 pertemuan dengan inisial peserta didik PKL dari kelompok 1, SAH, JAM, NKAD dari kelompok 3, RMBLNS, NSM dari kelompok 4, MMS, ARW, WP dari kelompok 5, dan FAP dari kelompok 6. Peserta didik tersebut memiliki kuantitas keterampilan berpendapat yang tinggi karena peserta didik tersebut memiliki keberanian, rasa percaya diri yang tinggi, dan juga mereka telah memahami materi yang diberikan guru secara mendalam sehingga peserta didik termotivasi dari dalam diri maupun lingkungan kelas untuk mengemukakan pendapatnya.

Pada kualitas keterampilan bertanya peserta didik dianalisis dengan menggunakan tingkatan bertanya Taksonomi Bloom yaitu C1C4. Data persentase jumlah peserta didik yang memperoleh predikat kualitas bertanya setiap pertemuan ditunjukkan pada Tabel 5 .

Tabel 5 Persentase Jumlah Peserta Didik yang Memperoleh Predikat Kualitas Bertanya.

\begin{tabular}{ccccc}
\hline \multirow{2}{*}{$\begin{array}{c}\text { Perte- } \\
\text { muan }\end{array}$} & \multicolumn{4}{c}{$\begin{array}{c}\text { Persentase (\%) jumlah peserta didik } \\
\text { dengan kualitas bertanya }\end{array}$} \\
\cline { 2 - 5 } & $\begin{array}{c}\text { Kurang } \\
\text { sekali }\end{array}$ & Kurang & Baik & $\begin{array}{c}\text { Baik } \\
\text { sekali }\end{array}$ \\
$\mathbf{1}$ & 75 & 16,67 & 00,00 & 8,33 \\
$\mathbf{2}$ & 55,56 & 33,33 & 00,00 & 11,11 \\
$\mathbf{3}$ & 44,44 & 30,56 & 00,00 & 25 \\
\hline
\end{tabular}

Keterangan:

Kurang sekali $=$ Peserta didik yang tidak pernah mengajukan pertanyaan.

Kurang $\quad=$ Peserta didik mengajukan pertanyaan pada tingkat Taksonomi Bloom C1-C2 sebanyak satu kali.

Baik =Peserta didik mengajukan pertanyaan pada tingkat Taksonomi Bloom C1-C2 lebih dari satu kali.

Baik sekali =Peserta didik mengajukan pertanyaan pada tingkat Taksonomi Bloom C3-C4 minimal satu kali ataupun lebih.

Pada data Tabel 5 menunjukkan persentase kualitas keterampilan bertanya pada predikat "baik sekali" mengalami kenaikan disetiap pertemuannya. Keterampilan bertanya peserta didik ini berhubungan dengan keterlaksanaan sintak pembelajaran model kooperatif tipe NHT dimana dengan model pembelajaran ini dapat memberikan motivasi peserta didik agar tertarik pada materi yang akan dipelajari, seperti pada fase pertama pembelajaran kooperatif adalah menyampaikan tujuan serta memberi motivasi peserta didik. Pada fase ini memiliki tujuan untuk memotivasi peserta didik dan menumbuhkan rasa keingintahuan peserta didik yang nantinya akan memunculkan pertanyaan-pertanyaan dari peserta didik. Motivasi dapat dipandang sebagai suatu proses dalam diri orang-orang yang bisa membuat orang lain dapat melakukan tindakan tertentu (Nur, 2008). Pembelajaran dapat berjalan dengan baik jika proses berkomunikasi berjalan dengan efektif dan lancar sehingga peserta didik diharapkan bersifat responsif dengan mengajukan pertanyaan.

Contoh salah satu pertanyaan diajukan oleh peserta didik yang termasuk dalam kategori C4 yaitu "Mengapa teori asam basa Arrhenius hanya terbatas pada pelarut air?". Pertanyaan tersebut termasuk dalam tingkat Taksonomi Bloom C4 karena pertanyaan tersebut mengaitkan antara teori asam basa dengan kelemahan teori asam basa Arrhenius, sehingga menganalisis kelemahan dari teori tersebut. Penjelasan dari pertanyaan tersebut adalah teori Arrhenius hanya terbatas palarut air karena apabila pelarutnya bukan air maka zat yang terurai tidak dapat menghasilkan ion $\mathrm{H}^{+}$dan $\mathrm{OH}^{-}$.

Pada kualitas keterampilan berpendapat peserta didik dianalisis dengan skor 0-3 dengan aspek yang diamati berdasarkan keanalitisan dan kelogisan pendapat yang disampaikan peserta didik. Pendapat peserta didik dikategorikan sebagai pendapat yang analitis apabila pesan disampaikan secara sistematis dan teratur. Makna dari kata sistematis dan teratur adalah pesan tersebut disusun berdasarkan kaidah berbahasa Indonesia yang baik, penyusunan kata yang baik dan jelas tidak berbelit-belit, serta pendapat yang disampaikan dapat dimengerti oleh orang lain. Sedangkan pendapat peserta didik dikategorikan sebagai pendapat yang logis apabila pesan yang disampaikan harus didukung beberapa alasan berbentuk fakta dan argumen yang dapat mndukung materi yang disajikan (Cangara, 2016).

Kualitas keterampilan komunikasi berpendapat ini diukur dengan menggunakan 
instrumen lembar pengamatan kualitas keterampilan komunikasi berpendapat. Data persentase jumlah pada peserta didik yang memperoleh predikat kualitas berpendapat setiap pertemuan ditunjukkan Tabel 6 .

Tabel 6 Persentase Jumlah Peserta Didik yang Memperoleh Predikat Kualitas Berpendapat.

\begin{tabular}{cccccc}
\hline \multirow{3}{*}{ Pertemuan } & \multicolumn{5}{c}{ Persentase (\%) jumlah peserta didik dengan kualitas berpendapat } \\
\cline { 2 - 6 } & Kurang & Kurang & Cukup & Baik & Baik sekali \\
& sekali & & & & \\
$\mathbf{1}$ & 58,33 & 00,00 & 8,33 & 27,78 & 5,56 \\
$\mathbf{2}$ & 38,89 & 2,78 & 11,11 & 22,22 & 25 \\
$\mathbf{3}$ & 25 & 00,00 & 8,33 & 38,89 & 27,78 \\
\hline
\end{tabular}

Keterangan:

Kurang sekali

Kurang

Cukup

Baik

Baik sekali
$=$ Peserta didik yang tidak pernah menyampaikan pendapatnya.

=Peserta didik yang menyampaikan pendapat sebanyak satu kali namun tidak mencapai aspek analitis dan logis.

=Peserta didik yang menyampaikan pendapat sebanyak satu kali dan pendapat yang disampaikan hanya mencapai aspek analitis atau aspek logis saja.

$=$ Peserta didik yang menyampaikan pendapat sebanyak satu kali dan pendapat yang disampaikan secara analitis dan logis.

$=$ Peserta didik yang menyampaikan pendapat minimal sebanyak dua kali maupun lebih dan pendapat yang disampaikan secara analitis dan logis.

Pada data Tabel 6 menunjukkan persentase kualitas keterampilan berpendapat pada predikat "baik sekali" mengalami peningkatan setiap pertemuannya. Berdasarkan data tersebut membuktikan bahwa keterampilan berpendapat peserta didik telah dilatihkan dan didukung dengan keterlaksanaan sintaks model pembelajaran kooperatif tipe NHT yang mendapatkan predikat sangat baik. Pembelajaran berjalan dengan baik jika proses komunikasi berjalan dengan efektif dan lancar sehingga peserta didik diharapkan bersifat responsif dengan menyampikan pendapatnya.

Contoh salah satu pendapat diajukan oleh peserta didik yang termasuk dalam kategori analitis dan logis yaitu "Menurut kelompok kami, kelemahan asam basa
Bronsted-Lowry adalah sulit menentukan keasaman suatu zat karena tergantung pada pasangan reaksinya". Pendapat tersebut termasuk dalam kategori logis karena dilandasi dengan fakta-fakta yang mendukung materi. Pendapat tersebut juga termasuk analitis karena telah sesuai dengan kaidah bahasa indonesia yang baik, penyusunan kata yang baik dan jelas sehingga tidak berbelit-belit dan dapat dimengerti.

\section{Hasil Belajar sebagai Data Pendukung}

Hasil belajar pada peserta didik diperoleh dari hasil posttest yang dikerjakan individu di akhir pertemuan dengan jumlah soal 15 butir soal pilihan ganda. Posttest ini memiliki tujuan untuk mengetahui kemampuan kognitif dari peserta didik pada materi asam basa setelah penerapan pembelajaran model kooperatif tipe NHT. Hasil belajar peserta didik dikatakan tuntas apabila sudah mencapai nilai $\geq 75$ dan dianggap tuntas secara klasikal jika sebanyak $75 \%$ peserta didik telah memperoleh nilai $\geq 75$.

Pada hasil posttest terdapat 33 peserta didik dikatakan tuntas dan 3 peserta didik yang berinisial MNA, IFW, dan MMA hasil belajarnya tidak tuntas meskipun telah diterapkan pembelajaran model kooperatif tipe NHT. Ketuntasan klasikal pada hasil belajar peserta didik yaitu sebesar 93,67\%.

Faktor ketidaktuntasan peserta didik jika dilihat dari segi materi disebabkan karena peserta didik dengan inisial MMA dan IFW yang memperoleh nilai posttest 60 memilih jawaban salah pada soal nomor 4, 5, 6, 11, 14, dan 15. Sedangkan MNA yang memperoleh nilai posttest 73 memilih jawaban salah pada soal nomor $6,8,11$, dan 15 . Pada soal dengan nomor 4, 5, dan 6 merupakan soal yang berkaitan dengan sub materi perkembangan 
teori asam basa. Soal dengan nomor 8 dan 11 berkaitan dengan sub materi identifikasi sifat asam basa. Serta soal dengan nomor 14 dan 15 berkaitan dengan sub materi penentuan $\mathrm{pH}$ larutan berdasarkan trayek. Berdasarkan hasil tersebut maka penyebab peserta didik tidak tuntas karena kurang memahami materi. Hal ini disebabkan karena pada saat diterapkan pembelajaran model kooperatif tipe NHT terdapat aktivitas yang tidak relevan selama dalam kegiatan pembelajaran berlangsung seperti bergurau dan bermain handphone, sehingga menyebabkan mereka tidak fokus mengikuti kegiatan pembelajaran.

Ditinjau dari keterampilan komunikasi selama 3 pertemuan IFW dari kelompok 2 tidak memiliki kuantitas bertanya sehingga mendapatkan predikat kualitas bertanya "kurang sekali", namun IFW pernah satu kali mengemukakan pendapat sehingga mendapat predikat kualitas komunikasi berpendapat "baik". Selama 3 pertemuan MMA dari kelompok 6 tidak pernah mengajukan pertanyaan maupun mengemukakan pendapatnya, sehingga mendapatkan kualitas keterampilan komunikasi bertanya maupun berpendapat dengan predikat "kurang sekali". Selama 3 pertemuan MNA pernah satu kali mengajukan pertanyaan dan mendapatkan kualitas komunikasi bertanya "kurang" serta mengemukakan pendapat sebanyak satu kali dengan kualitas komunikasi "baik".

Selain itu terdapat peserta didik dengan hasil belajar tinggi mempunyai keterampilan komunikasi yang rendah seperti peserta didik dengan inisial GCJS, HSP, MBRA, dan MH. Hal ini disebabkan karena peserta didik tersebut tidak dapat mengkomunikasikan pikirannya secara tepat dan jelas sehingga peserta didik tersebut malu dan tidak berani untuk berkomunikasi. Meskipun begitu pada saat proses pelajaran peserta didik tersebut selalu fokus dalam kegiatan pembelajaran dengan selalu mendengarkan dan memperhatikan temannya yang bertanya dan berpendapat sehingga mereka paham dengan materi pembelajaran. Hal tersebut membuat peserta didik mempunyai hasil belajar tinggi. Hal ini sejalan dengan teori adanya faktor dari dalam individu yaitu kecerdasan intelektual (IQ). Kecerdasan intelektual adalah kemampuan untuk menalar, memecahkan suatu masalah, berpikir abstrak, daya tangkap, pemahaman dalam belajar dan motivasi berprestasi. Daya tangkap dan pemahaman setiap peserta didik berbeda-beda dalam menerima suatu materi. Motivasi dari dalam individu juga sangat berpengaruh, dimana jika peserta didik tidak mempunyai motivasi dalam proses belajar maka hasil belajar yang didapatkan tidak akan optimal.

Hasil posttest memperlihatkan terdapat peserta didik mempunyai hasil belajar tinggi dan juga keterampilan komunikasi tinggi seperti PKL, NKAD, RMBLNS, dan FAP. Hal ini sejalan dengan teori bahwa satu unsur yang terpenting dalam keterampilan komunikasi adalah untuk menentukan hasil belajar akademik (Ibrahim, 2000). Hal ini karena terjadi pemindahan ilmu dari yang memberi pesan (komunikator) yaitu guru pada peserta didik atau dari peserta didik pada temannya yang lain sebagai penerima pesan (komunikan) (Rosyada, 2004). Oleh karena itu keterampilan komunikasi berkaitan dengan hasil belajar, karena digunakan sebagai data pendukung dilatihkannya keterampilan komunikasi.

Keterampilan komunikasi turut berperan dalam membagikan pengetahuan kepada peserta didik, dimana peserta didik yang awalnya tidak paham menjadi paham karena berkomunikasi. Sesuai dengan pembelajaran model kooperatif yang memiliki tujuan yakni hasil belajar di bidang akademik, penerimaan dalam perbedaan individu, dan dapat menumbuhkan keterampilan komunikasi yang meliputi keterampilan bertanya dan berpendapat (Ibrahim, 2000).

\section{SIMPULAN DAN SARAN}

1. Keterlaksanaan pembelajaran model kooperatif tipe NHT materi asam basa untuk melatih keterampilan komunikasi peserta didik memperoleh hasil rata-rata keterlaksanaan pada 3 pertemuan berurutan adalah 3,86; 3,90; dan 3,95 dengan memiliki kategori sangat baik, sehingga memperlihatkan bahwa pembelajaran model kooperatif tipe NHT yang telah dilakukan selama 3 pertemuan terlaksana dengan baik.

2. Peserta didik menggunakan waktunya untuk berlatih keterampilan komunikasi bertanya selama 3 pertemuan sebesar 14,07\% sedangkan untuk keterampilan komunikasi berpendapat peserta didik menggunakan 
waktunya sebesar 66,29\%. Hal ini menunjukkan bahwa persentase aktivitas peserta didik yang relevan dengan keterampilan komunikasi lebih besar dibanding persentase aktivitas yang tidak relevan. Sehingga dapat dikatakan bahwa aktivitas peserta didik terlaksana dengan baik.

3. Keterampilan komunikasi pada peserta didik mencakup kuantitas serta kualitas bertanya dan berpendapat. Untuk kuantitas bertanya peserta didik memperoleh kriteria penilaian cukup dengan persentase selama tiga pertemuan berturut-turut sebesar $25 \%$; $44,44 \%$; dan $55,56 \%$ serta kuantitas berpendapat peserta didik memperoleh kriteria penilaian baik selama tiga pertemuan sebesar 41,67\%; 61,11\%; dan $75 \%$. Hal ini memperlihatkan bahwa kuantitas bertanya serta berpendapat memperoleh peningkatan disetiap pertemuan. Pada kualitas bertanya peserta didik memperoleh predikat baik sekali selama tiga pertemuan berurutan sebesar $8,33 \%$; $11,11 \%$; dan $25 \%$ serta kualitas berpendapat peserta didik memperoleh predikat baik sekali selama tiga pertemuan sebesar 5,56\%; 25\%; dan 27,78\%. Hasil yang didapatkan memperlihatkan bahwa kualitas bertanya dan berpendapat mengalami kenaikan disetiap pertemuan.

\section{SARAN}

1. Pembelajaran pada model kooperatif adalah pembelajaran yang mana peserta didik belajar dengan membentuk kelompok kecil yang heterogen. Sehingga pada peneliti berikutnya, pengetahuan awal pada peserta didik digali dengan teliti agar pembagian kelompok pada model pembelajaran ini lebih heterogen dengan penggunaan desain One Group Pretest Posttest Design.

2. Pada saat melatihkan keterampilan komunikasi selama proses pembelajaran untuk peneliti berikutnya, peserta didik dilatihkan dan diberi tahu contoh-contoh pertanyaan yang berada pada tingkat Taksonomi Bloom C1-C6 dan contoh pendapat dengan aspek logis dan analitis sehingga keterampilan komunikasi dapat terlatih dengan baik.

3. Unsur yang terpenting sebagai penentu keberhasilan proses pembelajaran adalah keterampilan komunikasi. Oleh sebab itu agar mengetahui respon komunikasi peserta didik dalam kegiatan pembelajaran maka untuk peneliti berikutnya dibuat lembar angket respon peserta didik saat berlatih keterampilan komunikasi.

\section{DAFTAR PUSTAKA}

[1]Depdiknas. Peraturan Menteri Pendidikan dan Kebudayaan Nomor 69 Tahun 2013 Tentang Kerangka Dasar dan Struktur Kurikulum Sekolah Menengah Atas/Madrasah Aliyah. Jakarta: Badan Standar Nasional Pendidikan.

[2]Cangara, Hafied. 2016. Pengantar Ilmu Komunikasi. Jakarta: PT. Raja Grafindo Persada.

[3]Rosyada, Dede. 2004. Paradigma Pendidikan Demokratis. Jakarta: Prenada Media.

[4]Slavin, Robert. 2016. Cooperative Laerning Teori, Riset dan Praktik. Bandung: Nusa Media.

[5]Arends, Richard L. 2013. Learning To Teach Belajar untuk Mengajar. Penerjemah Made Frida Yulia. Jakarta: Salemba Humanika.

[6]Sugiyono. 2016. Metode Penelitian Pendekatan Kuantitatif, Kualitatif, dan R \& $D$. Bandung: Alfabeta.

[7]Riduwan. 2015. Skala Pengukuran Variabel-Variabel Penelitian. Bandung: Afabeta.

[8]Maryanti, Silya, Zikra, dan Nurfahanah. 2012. Hubungan Keterampilan Komunikasi dengan Aktivitas Belajar Siswa. Konselor Vol.1, No.2:1.

[9]Kosasih, E. 2014. Strategi Belajar dan Pembelajaran Implementasi Kurikulum 2013. Bandung: Yrama Widya.

[10]Nur, Mohamad., Wikandari, Prima Retno. 2008. Pengajaran Berpusat pada Siswa dan Pendekatan Konstruktivis dalam Pengajaran. Surabaya: Pusat Sains dan Matematika Sekolah Unesa.

[11]Ibrahim, Muslimin, dkk. 2000. Pembelajaran Kooperatif. Surabaya: UNESA-UniversityPress. 